\title{
Human Capital Investment and Economic Development: The Nigerian Experience
}

\author{
Olatunji A. Shobande ${ }^{1}$, Anthonia T. Odeleye ${ }^{1} \&$ Ndubisi C. Olunkwa ${ }^{1}$ \\ ${ }^{1}$ Department of Economics Caleb University, Imota-Lagos, Nigeria \\ Correspondence: Olatunji A. Shobande, Anthonia T. Odeleye, Department of Economics Caleb University, \\ Imota-Lagos, Nigeria. Tel: 234-803-271-2230. E-mail: olatunji.shobande@yahoo.com; antileye@yahoo.com
}

Received: May 27, 2014 Accepted: June 17, 2014Online Published: June 21, 2014

doi:10.5430/wjss.v1n2p107ＵRL: http://dx.doi.org/10.5430/wjss.v1n2p107

\begin{abstract}
The study examined the impact of human capital investment on economic development of Nigeria. The Solow augmented model developed by Mankiw, Romer, and Weil (1992) which incorporated the role of human capital as a yardstick for economic development was adapted to investigate the link between human capital investment and economic development in Nigeria.. Annual time series data sourced from the Central Bank of Nigeria's Statistical Bulletin between 1970 to 2011.Ordinary least square method (OLS), Augmented dickey fuller test (ADF), Johansen co-integration, Error correction model (ECM) were employed as estimation techniques. Pre-estimation findings showed that all variables are non-mean reverting at level and do not converge to their long run equilibrium until they were at first differenced. The empirical finding indicated that there was a negative short run relationship between economic development and human capital investment in Nigeria. It is recommended that Nigeria should consider education beyond secondary school enrollment, if investment in human capital is to produce meaningful macroeconomic changes.
\end{abstract}

Keywords: Human capital investment, Monetary policy, Fiscal policy, Economic development, Macroeconomic changes gross capital formation.

JEL Classification: E24, E63, F62

\section{Introduction}

Meier (1970) opines that human capital development concerns the twofold objective building skills and providing productive employment for non-utilised or underutilised manpower. Both stem from investment in man in the form of education and training which are known to be institutional mechanisms for enhancing people's knowledge, skills and capabilities. Odusola (1998) state that the concept of human capital development refers to a conscious and continuous process of acquiring and increasing the number of people with requisite knowledge, education, skill and experience that are crucial for the economic development of a country. The economic benefits of human capital development arise from making people more productive by improving their nutrition, health, education and other social indices through adequate and proper investments (Dauda, 2010).

Burnett et al (1995) claim that investing in human capital development raises per capita GNP, reduces poverty and supports the expansion of knowledge. Education, it is argued, reduces inequality. Fishlow (1995) agree that inequality is negatively related to growth. Stiglz (1998) also states that "successful development entails not only closing the gap in physical or even human capital, but also closing the gap in knowledge". Neoclassical growth theory (1957) seeks long-term relationship between accumulations of Human capital on growth. Cobb-Douglas (1927-47), Solow (1957), Swam (1956), all presented a unique model that link growth, physical capital and human capital. The framework of Mankiw, Romer and Weil (1992) seems to provide a broad answer to questions about the role of human capital in growth, using the adult population of secondary school enrollement as a proxy for human capital investment and gross domestic product (GDP) as regressand, this study examines the relationship between human capital investment and economic development in Nigeria.

Ogujiuba and Adeniyi (2010) state that the expansion in the educational system in Nigeria was accompanied by structural defects, inefficiency and ineffectiveness which affected her level of human capital development and 
utilisation. Nigeria's educational system tends to produce graduates who lack job skills for employment than those the economy requires to remain vibrant. This inadequacy resulted in decreasing industrial capacity utilization, rising unemployment, threats of social insecurity by jobless youths. Adawo (2011) argues that, despite efforts made towards building human capital through education, the impact of human capital investment on the economic growth in Nigeria is not clear.

In Nigeria, attempts have been made to conduct econometric studies on the link between Human capital development and growth, Chete and Adeoye (2003); Dauda (2010); Bakare (2006); Sanusi (2003) Yesufu (2000); Adamu (2003) among others. However, many of these previous studies were inconclusive and further statistical analysis was required to validate not only the actual impact of human capital investment on economic development but to logically reunite the recent economic theory with current economic reality in Nigeria. Against this background, the rest of this paper is organised as follows. Section two focuses on the theoretical underpinnings as well as review of previous studies while section three provides a robust description of the research methodology. In all, section four show the analysis and empirical result of the study while discussion and possible policy recommendation is the focus of section five.

\section{Literature Review}

Adam Smith (1776) incorporated the idea of labour specialization "an inquiry into the wealth of a nation". In attempts to justify the role of human capital in economic growth, he argued that all human beings are the same by birth, but education, skill and experience showed their differences. Alfred Marshall (1898), however, thought that the concept presented by Smith, lacked empirical usefulness due to measurement used in the study. Karl Marx (1883) in his views recognised the importance of human capital, but failed to indicate its importance to economic growth. Uzawa (1965) and Lucas (1988) revealed that the representative individual decided the proportion of his available resources spent on physical capital and human capital respectively.

Okojie (1995) reported that the human capital development is associated with investment in man and his development as a creative and productive person. He opined that it is a continuing process from childhood to old age, and a must for any society or enterprise that desire to survive under the complex challenges of a dynamic world. Human capital development is also a means since it enhances the skills, knowledge, productivity and inventiveness of people through a process of human capital formation broadly conceived.

Solow (1957), in his paper introduced the influence of technological progress in the production process as a solution to economic growth. The exclusion of human capital from the Solow model, recently received more attention as omitting human capital accumulation, which biases the estimated coefficient on savings and population growth. However, Solow`s analysis failed to incorporate and consider human capital investment as a yardstick for economic growth.

Tony Addison (2003) concluded that the underlying causes of unequal educational and other public spending were economic power and associated wealth provided by the affluent with a disproportionate influence over the political progress. The World Bank (1996) showed that on average, low income countries, especially Sub Saharan Africa spend substantially more on education for household in the richest Quintiles than those in the poorest once. Chong Kee Yip (1999) argued that because the engine of economic growth is human capital accumulation and inter generational externality, the brain drain has an adverse impact on present growth, income distribution and welfare of future generation of non-migrants.

Using United Nations data, Barro (1991) showed that it is difficult to get a valuable and accurate measure of human capital. He further stresses that unavailability of data that captured all the variability of total stock of human capital was the major challenges.

\section{Methodology}

\subsection{Model Specification}

The study employed Solow model augmented by Mankiw, Romer, Weil (1992) in their influential contribution to the theory of economic growth. They presented an extension of the Solow model to incorporate human capital and stress the role of knowledge on economic growth. They make three important contributions by postulating that people invest in human capital just like in physical capital and that human capital depreciated at the same constant rate. Physical capital and output were used for consumption or investment, which are represented as: 


$$
\gamma_{t}=A K_{T}^{\infty} H_{f}^{Q}
$$

Linearized thus:

$$
\operatorname{InY} Y_{F}=\operatorname{InA}+\times \operatorname{In} K_{p}+\beta \operatorname{In} H_{p}+\boldsymbol{F}
$$

Where $Y$ is real GDP and $K$ is physical capital while $H$ is human capital, $\alpha$ and $\beta$ are parameter coefficients, and $A$ is efficiency parameter or constant.

The study drew an insight from Haldar \& Mallik (2010) model borrowed from McMahon (1998) and Oketch (2006) analysis which inferred that human capital caused economic growth. They extended the formulation to incorporate other explanatory variables such as school enrollment. This study incorporated both monetary policy and foreign policy as control variables. The adapted model is:

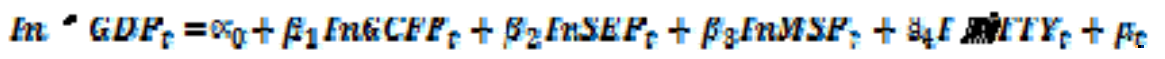

Where; PGDP is economic growth and development proxy by GDP per capita; GCFP is investment proxy by gross capital formation per capita; MSP is monetary policy proxy by money supply per capita; SEP is human capital development proxy by secondary education per capita; TTP is foreign policy proxy by trade balance per capita; $\alpha_{0}$ Is constant; $\beta_{4} \beta_{3} \beta_{3}, \beta_{4}$ are parameter coefficients; $\mu_{t}$ is error term and $t$ is the time period. Pre-estimation tests such as Augment Dickey Full Test (ADF) and Johansen co-integrated and post-estimation tests $\left(\mathrm{R}^{2}\right.$, t-test, F-test, Durbin Watson, Error Correction Model (ECM) test), Ramsey reset, Normality test (Jargua Bera Test) etc were carried out. Data were sourced from Central Bank of Nigeria (CBN) Statistical Bulletin and annual report and statement of account, Publications of National Bureau of Statistic (NBS).

\section{Empirical Results}

This section of the study presents descriptive statistics, estimated multiple regression and diagnostic test results.

\subsection{Descriptive Statistics}

The summary of the empirical analysis presented in Table 1 below reports that the mean value of the log of GDP per capita (PGDP), gross capital formation per capita (GCFP), money supply per capita (MSP), secondary education per capita (SEP) and trade balance per capita (TTP) are $8.51 \%, 5.50 \%, 6.46 \%,-3.65 \%$ and $7.89 \%$ respectively. The probability value of the Jarque-Bera statistics for all variables shows their distribution level at mean zero and constant variance. Figure 1(see Appendix) depicting their graphical movements reveals that variables have an upward trend during the review period.

Table 1. Statistical Summary of the Variables used in the Regression Analysis

\begin{tabular}{llllll}
\hline & LPGDP & LGCFP & LMSP & LSEP & LTTP \\
\hline Mean & 8.509885 & 5.499486 & 6.455473 & -3.646390 & 7.893090 \\
Median & 7.993293 & 4.807017 & 6.029025 & -3.440281 & 7.641924 \\
Maximum & 12.35612 & 7.987384 & 10.54164 & -2.838247 & 12.07161 \\
Minimum & 5.051393 & 2.861650 & 2.416223 & -5.080538 & 3.422803 \\
Std. Dev. & 2.409271 & 1.727316 & 2.479060 & 0.635729 & 2.759785 \\
Observations & 42 & 42 & 42 & 42 & 42 \\
\hline
\end{tabular}

Source: Authors' computation, 2014.

\subsection{Unit Root Test Results}

This sub-section presents the pre-test analysis before estimating the long-run relationship between human capital development and economic growth in Nigeria (1970-2011). The variables used for our analysis are subjected to two types of unit root test (Augmented Dickey Fuller and Phillip Perron) to determine whether they are unit roots or stationary series. The results are presented in Table 2 below. The null hypothesis in both the ADF and PP test is the presence of unit root. 
Table 2. Unit Root Test Results

\begin{tabular}{|c|c|c|c|c|c|}
\hline \multirow{2}{*}{ Variables } & \multicolumn{2}{|c|}{ Augmented Dickey Fuller Test (ADF) } & \multicolumn{2}{|l|}{ Phillip-Perron } & \multirow{2}{*}{ Remarks } \\
\hline & Levels & First Difference & Levels & First Difference & \\
\hline GCFP & $-2.277(0)[-4.199]$ & $-6.888(0)[-4.205]^{*}$ & $-2.239(1)[-4.199]$ & $-6.888(0)[-4.205]^{*}$ & $\mathrm{I}(1)$ \\
\hline MSP & $-2.680(1)[-4.205]$ & $-4.599(0)[-4.205]^{*}$ & $-2.151(1)[-4.199]$ & $-4.599(0)[-4.205]^{*}$ & $\mathrm{I}(1)$ \\
\hline PGDP & $-1.864(1)[-4.205]$ & $-4.661(0)[-4.205]^{*}$ & $-1.844(3)[-4.199]$ & $-4.653(2)[-4.205]^{*}$ & $\mathrm{I}(1)$ \\
\hline SEP & $-2.135(1)[-4.205]$ & $-3.385(0)[-3.195]^{* * *}$ & $-1.804(4)[-4.199]$ & $-3.435(3)[-3.195]^{* * *}$ & $\mathrm{I}(1)$ \\
\hline TTP & $-2.902(3)[-4.219]$ & $-5.298(0)[-4.205]^{*}$ & $-1.912(4)[-4.199]$ & $-5.415(4)[-4.205]^{*}$ & $\mathrm{I}(1)$ \\
\hline$e c t_{t}$ & $-3.148(0)[-3.601]^{* *}$ & $-5.020(2)[-3.616]^{*}$ & $-2.994(2)[-3.601]^{* *}$ & $-6.729(5)[-3.606]^{* *}$ & $\mathrm{I}(0)$ \\
\hline
\end{tabular}

Note: * significant at $1 \%$; ** significant at $5 \% ; * * *$ significant at $10 \%$ Mackinnon critical values and are shown in parenthesis. The lagged numbers shown in brackets are selected using the minimum Schwarz and Akaike Information criteria.

Source: Authors' computation, 2014.

Thus, all the variables using both ADF and PP are non-mean reverting at levels and do not converge to their long-run equilibrium until they are first differenced. However, econometric literature argued that if two or more series are I(1) series then, it is possible that their residuals are stationary i.e. I(0). Hence, the long-run association among the series based on generated residual was also determined. The result of the long-run estimate is presented in Table 3 . From the generated residual term, its null hypothesis stipulating the existence of "random walk" was rejected at $1 \%$ significance level.

Table 3. Result for Long-run Estimate

\begin{tabular}{lllll}
\hline Variable & Coefficient & Std. Error & t-Statistic & Prob. \\
\hline C & 0.433502 & 0.400059 & 1.083595 & 0.2856 \\
LGCFP & 0.190212 & 0.074762 & 2.544239 & 0.0153 \\
LMSP & 0.481880 & 0.085609 & 5.628874 & 0.0000 \\
LSEP & -0.267259 & 0.080892 & -3.303895 & 0.0021 \\
LTTP & 0.373113 & 0.082433 & 4.526251 & 0.0001 \\
\hline
\end{tabular}

Adjusted $R^{2}=0.996, F$-stat $=2307.857(0.000), D W=0.647$

Source: Authors' computation, 2014.

The Johansen (1988) co-integration test is also applied to test whether the linear combinations of the variables could result in a long-run relationship among the variables. The co-integration result is presented in Table 4.

Table 4. Co-integration Test Results

Hp: rank $=\mathrm{p}($ no deterministic trend in the data)

Hr: rank $\mathrm{r}<\mathrm{p}$ (co-integration relations)

\begin{tabular}{|c|c|c|c|c|c|}
\hline \multirow{2}{*}{$\begin{array}{l}\text { Hypothesized } \\
\text { No. of CE(s) }\end{array}$} & \multirow[b]{2}{*}{ Eigenvalue } & \multicolumn{2}{|l|}{ Trace Statistics } & \multicolumn{2}{|c|}{ Max-Eigen Statistics } \\
\hline & & Likelihood Ratio & $\begin{array}{l}0.05 \\
\text { Critical Value }\end{array}$ & Likelihood Ratio & $\begin{array}{l}0.05 \\
\text { Critical Value }\end{array}$ \\
\hline None * & 0.617247 & 93.01537 & 69.81889 & 37.45430 & 33.87687 \\
\hline At most $1 *$ & 0.500824 & 55.56107 & 47.85613 & 27.09703 & 27.08434 \\
\hline At most 2 & 0.427853 & 28.46404 & 29.79707 & 21.77600 & 21.93162 \\
\hline At most 3 & 0.157247 & 6.688045 & 15.49471 & 6.672194 & 14.26460 \\
\hline At most 4 & 0.000406 & 0.015851 & 3.841466 & 0.015851 & 3.841466 \\
\hline
\end{tabular}

* denotes rejection of the hypothesis at $5 \%$ significance level

Likelihood ratio test of both Trace and Max-Eigen indicates 2 co-integrating equation(s)

Source: Authors' computation, 2014. 
The outputs of Table 4show that the null hypothesis of no co-integrating vector is rejected at none and at most one co-integrating vector at $1 \%$ significance level, but the null hypothesis for at most 2 co-integrating vector is accepted both at $1 \%$ and $5 \%$ respectively. This means that there are two co-integrating vectors in the model specified in this study.

\subsection{Over Parameterized, Parsimonious Regression Estimates and Higher-Order test}

After the co-integration test, we over parameterized the variables in the model and used Schwarz Information Criteria to guide parsimonious reduction of the model. The over parameterised result helps to identify the main dynamic pattern in the model, which is presented in Table 5. It further ensures that the dynamic pattern of the model has not been constrained by inappropriate lag length specification.

Table 5. Over Parameterized Regression Estimates

\begin{tabular}{lllll}
\hline Variable & Coefficient & Std. Error & t-Statistic & Prob. \\
\hline C & 0.048287 & 0.033997 & 1.420352 & 0.1662 \\
D(LGCFP) & 0.001926 & 0.051022 & 0.037756 & 0.9701 \\
D(LMSP) & 0.196793 & 0.095457 & 2.061577 & 0.0483 \\
D(LSEP) & -0.206495 & 0.207781 & -0.993810 & 0.3285 \\
D(LTTP) & 0.438584 & 0.068497 & 6.402935 & 0.0000 \\
D(LPGDP(-1)) & 0.175098 & 0.165249 & 1.059601 & 0.2981 \\
D(LGCFP(-1)) & 0.039300 & 0.056635 & 0.693912 & 0.4933 \\
D(LMSP(-1)) & -0.160655 & 0.102931 & -1.560812 & 0.1294 \\
D(LSEP(-1)) & 0.129818 & 0.217827 & 0.595969 & 0.5558 \\
D(LTTP(-1)) & -0.011954 & 0.098918 & -0.120849 & 0.9046 \\
ECM(-1) & -0.337397 & 0.119507 & -2.823239 & 0.0085 \\
\hline Adjusted $R^{2}=0.705, F-$ stat $=10.296(0.000), D W=1.962$ &
\end{tabular}

Source: Authors' computation, 2014.

However, the results for the parsimonious error correction model (Table 6 below) showed that the adjusted co-efficient of determination was able to explain $73.2 \%$ of variation in economic growth (development) in Nigeria. The remaining $26.8 \%$ can be attributed to the influence of omitted variables such as fiscal policy, external sector policy, etc. Moreover, the overall test (18.811) indicated that the model fits the data relatively well while the Durbin-Watson statistics (1.853) which is approximately two (2) revealed absence of autocorrelation. However, the coefficient of determination with a value of $55.9 \%$ is still lower than the Durbin-Watson value, which denotes the non-spuriousness of the model.

The co-efficient of individual variables was also examined to determine the relative contributions of each variable to economic growth (development) in Nigeria. Empirical evidence shows that there is negative short-run relationship between economic growth and secondary school enrolment per capita in Nigeria, which was found insignificant at $5 \%$ level of significance. A negative relation was also observed to exist between first lag of money supply per capita and economic growth, and was significant at $10 \%$ significant level. On aggregate, a $10 \%$ increase in changes in secondary school enrolment per capital and first lag of money supply per capita deteriorated Nigerian economic growth by $1.57 \%$ and $1.75 \%$ respectively. Both variables are inconsistent with the set apriori expectations.

In addition, there exists a positive short-run impact from changes in money supply and trade balance per capita and the first lag of GDP per capita to economic growth and development, which were also found to be consistent with the theoretical foundation. In terms of magnitude effect, a 10\% change in money supply and trade balance per capita and the first lag of GDP per capita boost or increase the growth rate of the Nigerian economy by $2 \%, 4.27 \%$ and $1.65 \%$ respectively. The residuals from the parsimonious error correction model formulated show the variability in its error term, which is depicted in Figure 2 (see Appendix). 
Table 6. Parsimonious Error Correction Regression Estimates

\begin{tabular}{|c|c|c|c|c|}
\hline Variable & Coefficient & Std. Error & t-Statistic & Prob. \\
\hline$\overline{\mathrm{C}}$ & 0.060754 & 0.028651 & 2.120484 & 0.0416 \\
\hline D(LMSY) & 0.200030 & 0.086312 & 2.317516 & 0.0268 \\
\hline D(LSEY) & -0.157440 & 0.167216 & -0.941538 & 0.3533 \\
\hline D(LTTY) & 0.427006 & 0.061566 & 6.935716 & 0.0000 \\
\hline D(LPGDP(-1)) & 0.164778 & 0.102615 & 1.605785 & 0.1178 \\
\hline D(LMSY(-1)) & -0.174660 & 0.095170 & -1.835239 & 0.0755 \\
\hline ECM(-1) & -0.363649 & 0.102192 & -3.558496 & 0.0012 \\
\hline R-squared & 0.7738 & \multicolumn{2}{|c|}{ Durbin-Watson stat } & 1.8534 \\
\hline Adjusted $\mathbf{R}^{2}$ & 0.7326 & \multicolumn{2}{|l|}{ F-statistic } & 18.8112 \\
\hline S.E. of regression & 0.0794 & \multicolumn{2}{|c|}{ Prob(F-statistic) } & 0.0000 \\
\hline \multicolumn{5}{|c|}{ Residual Normality Test } \\
\hline Jarque-Bera & 0.4842 & \multicolumn{2}{|l|}{ Prob(J.B) } & 0.7850 \\
\hline \multicolumn{5}{|c|}{ Breusch-Godfrey Serial Correlation LM Test } \\
\hline F-statistic & 0.1593 & \multicolumn{2}{|c|}{ Prob. F(2, 31) } & 0.8535 \\
\hline Obs*R-squared & 0.4068 & \multicolumn{2}{|c|}{ Prob. Chi-Square(2) } & 0.8159 \\
\hline \multicolumn{5}{|c|}{$\bar{H}$} \\
\hline \multicolumn{5}{|c|}{ Heteroskedasticity Test: Breusch-Pagan-Godfrey } \\
\hline F-statistic & 0.9113 & \multicolumn{2}{|c|}{ Prob. F(6,33) } & 0.4990 \\
\hline Obs*R-squared & 5.6857 & \multicolumn{2}{|c|}{ Prob. Chi-Square(6) } & 0.4593 \\
\hline
\end{tabular}

Source: Authors' computation, 2014.

The error correction variable estimate of 0.364 indicates that $36.4 \%$ of the preceding period's disequilibrium is eliminated in the current period, with immediate adjustments captured by the difference terms. The table also reports the probability value of the Jarque-Bera statistic (0.4842) shows that the estimated residual series is normally distributed with zero mean and constant variance. This tends to improve the reliability of the estimated parameters and thus, necessitate other residual diagnostic test such as higher order serial correlation and heteroskedasticity tests. The Breusch-Godfrey serial correlation test result from Table VI reported that we do not reject the null hypothesis "no serial correlation" at 5\% significance level, and likewise for the Breusch-Pagan-Godfrey heteroskedasticity test, the result indicated that we do not reject the null hypothesis "no heteroskedasticity" at 5\% significance level.

Table 7. Variance Inflation Factor (VIF)

\begin{tabular}{llll}
\hline Variable & Coefficient Variance & Uncentered VIF & Centered VIF \\
\hline C & 0.000821 & 5.212958 & NA \\
D(LMSY) & 0.007450 & 3.366304 & 1.422741 \\
D(LSEY) & 0.027961 & 1.958330 & 1.439401 \\
D(LTTY) & 0.003790 & 2.515617 & 1.477814 \\
D(LPGDP(-1)) & 0.010530 & 3.709020 & 1.520796 \\
D(LMSY(-1)) & 0.009057 & 4.065443 & 1.772433 \\
ECM(-1) & 0.010443 & 1.441256 & 1.436219
\end{tabular}

Source: Authors' computation, 2014. 
Thus, Table 7 above shows that there is no multi-collinearity among the explanatory variables incorporated in the estimated parsimonious error correction model as evaluated by the centered Variance Inflation Factor (VIF).

\section{Discussion and Policy Outlooks}

This study investigated the nexus between human capital development and economic growth in Nigeria. We used Ordinary Least Square econometric model to estimate the effect of gross capital formation, money supply, secondary school enrollment and trade balance on economic growth (development). The results revealed that all the variables were found to be co-integrated of order one. The dynamics of the model were not constrained by an inappropriate lag-length specification which was illustrated by Schwarz information criteria. Further, the error correction model showed that the explanatory variables accounted for approximately $73.3 \%$ variation on economic growth (development).

From the empirical results, it was found that the secondary school enrolment has a negative and insignificant effect on per capita GDP growth whereas money supply in previous years has a significant effect. The schooling rate was consistent to the results by Caselli, Esquivel \& Lefort (1996) that a negative relationship exists between school enrolment and output per capita. This negates studies carried out by Bills and Klenow (2000), Self and Grabowski (2004) that schooling is positively correlated with the growth rate of per capita GDP. Unlike secondary enrolment, we found that money supply and per capital GDP in previous years are very important and have significant positive long run effect on per capita GDP growth as well as trade balances but the P value shows that the variables were not significant. These were found to be consistent with the findings of Ajayi \& Atanda (2012) and Alimi and Atanda (2012) that trade balances have positive and significant effects on economic growth of Nigeria.

Although, the government of Nigeria has initiated various policies and programmes in the direction of human capital development since independence but progress is very slow compared to many developing countries.Recognising the contribution of secondary school enrolment to economic growth (development) and keeping in line with the human capital investment revolution in economic thought, the government of Nigeria needs to increase its public expenditure spending or quota on education. Strategic macroeconomic policies should be put in place in order to encourage domestic private investment from both home and abroad towards human capital development because of its significant capacity to enhance the growth of the Nigerian economy.

\section{References}

Adamy P.A. (2003). The impact of Human Capital Formation on Economic Development in Nigeria. An Error Correction Approach In: Human Resource Development in Africa. Selected Papers for 2002 Annual Conference Nigerian Economic Society Ibadan. pp. 53-56.

Adawo M.A. (2010). Has Education (Human Capital) Contributed to Economic Growth in Nigeria? Journal of Economics and International Finance, 3(1), January,46-58.

Adedeji S.O.,\& R.O. Bamidele. (2003). Economics Impact of Tertiary Education on Human Capital Development in Nigeria; Human Resource development in Africa. Selected papers for 2002 annual conference, Nigerian Economic society, Ibadan. pp. 499-501.

Akangbon S.D. (1983). Cost Benefit Analysis of Educational Investment in Benue State of Nigeria. Journal of Nigerian Education Research Association, 3(2), June, 29-38.

Barro R. (1991). Economic Growth in a Cross-Section of Countries Quarterly Journal of Economic 10611. pp 407-437. [8]. Blang M (1976) "Human Capital Theory, a Slightly Jaundiced Survey” J. Econ Lit 9, pp. 827-855.

Burneth, N. K., Marble,\& H.A Patrinos. (1995).Setting Investment Priorities in Education Finance and Development: Development. pp. 42-45.

Dauda, R.O. (2010). Role of Human Capital in Economic Development: An Empirical Study of Nigeria Case, Selected Papers for 2010. UK: Oxford Business and Economic Conference Program.

Harbison, F. H. (1973).Human Resources as the Wealth of Nations. New York: Oxford University Press.

Kyriacon, G. (1980). Level and Growth Effects of Human Capital: A Cross Country Study of the Convergence Hypothesis. New York: University, Economic Research Report. p. 91.

LAN, L.D., \& Jamison L. L. (1991). Impact of Education by Region, World Bank. Washington, D.C. Processed. 
Mankiw, G., D. Romer,\& D. Weil. (1992). A Contribution to the Empirics of Economics 107. pp. 407-437.

Meier, G.M (1970).Leading Issues in Economic Development(2nd ed.). Oxford: Oxford University Press.

Ndiyo. (2002). "The Paradox of Education and Economic Growth in Nigeria: An Empirical Evidence" NES Proceedings.

Odusola, A.F. (1998). Human Capital Investment and the Empirics of Economic Growth in Nigeria, In Rekindling Investment for Economic Development in Nigeria Selected Papers for 1998 NES Annual Conferences, Ibadan: Nigerian Economic Society. pp. 257-272.

Okojie, C.E.E (1995). Human Capital Formation for Productivity Growth in Nigeria.Nigerian Economic and Financial Review, 3, December, 71-102.

\section{Appendix}
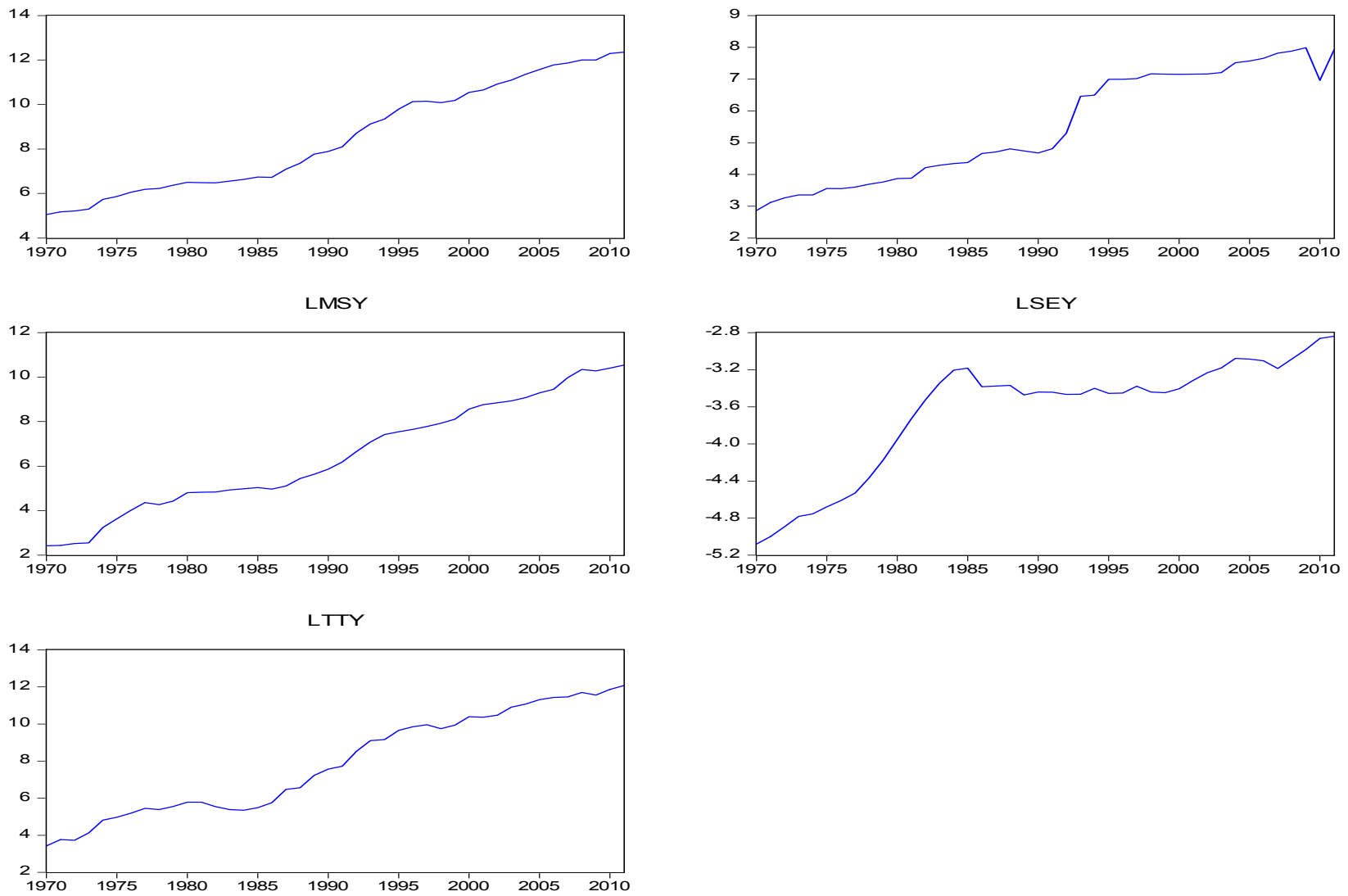

Figure 1. Time Series Plots of Human Capital Development Indicators and Economic Growth in Nigeria 


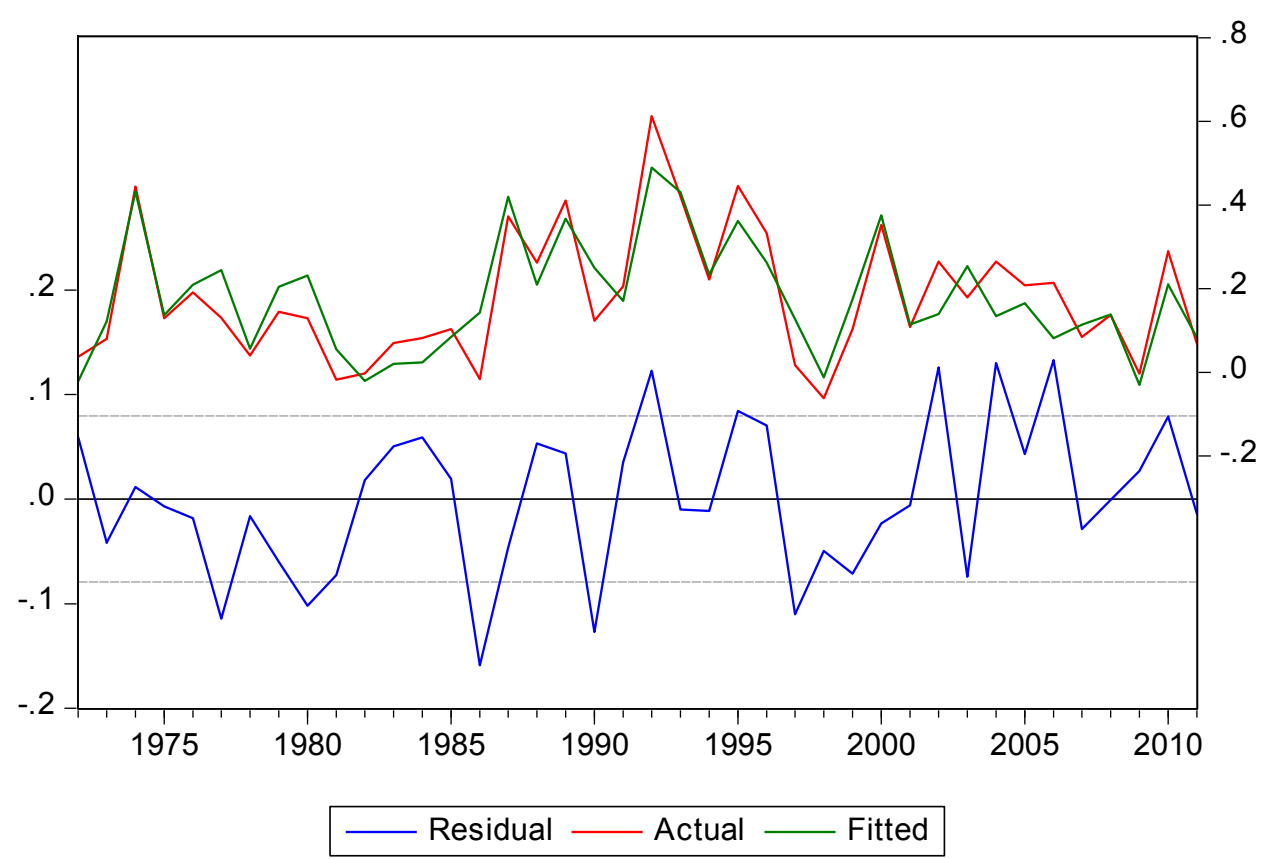

Figure 2. Residual Graph 